\title{
ON THE ISSUE OF CARRYING OUT OF RUMMAGE ON THE BASIS OF AUTHORIZATION OF LAW ENFORCEMENT AGENCY
}

The purpose of the research is installation of essential characteristics of implementation of rummage (revision) of goods and vehicles of commercial purpose on the initiative of law enforcement agencies.

Methodological basis of scientific research, logic of idea of the studied material were general and special methods of scientific knowledge: method of system analysis, dialectical method, formal-logical method and structural functional, and also a number of empirical methods.

Results. The article reveals theoretical-applied aspects of carrying out of rummage (revision) of goods, vehicles of commercial purpose on the basis of written authorization of law enforcement agencies. The order of interaction between customs authorities and law enforcement agencies is analyzed at the part of implementation of customs formalities. A discrepancy has been established between norms of current customs legislation at the part of encroachment on the exclusive competence of customs authorities regarding implementation of customs control and volume selection of customs formalities from the side of law enforcement agencies. Attention is paid to condition of realization of experimental project on the organization of centralized sending by law enforcement agencies in electronic form of orders for customs inspection (reinspection) of goods, commercial vehicles. The directions of further use of information telecommunication technologies during interaction of customs and law enforcement agencies are offered.

Conclusions. "Rummage" is defined as one of forms on customs control, the implementation of which is attributed to the exclusive competence of officials of the customs authority, which is to carry out a set of actions for visual and factual inspection of goods and vehicles for commercial purposes, which are under customs control, aimed at verifying the factual data, as stated in the documents and/for compliance with customs legislation. Herewith, the choice of grounds and limits of customs inspection is carried out exclusively within the limits set by the Customs Code of Ukraine. Artificial expansions of individual elements of mechanism of carrying out of rummage (revision) of goods, vehicles of commercial purpose on the basis of by-laws are a violation of the rule of law. A two-step approach to reform is proposed for rummage (revision) of goods, vehicles of commercial purpose on the basis of written authorization of law enforcement agencies. On the first step is proposed establishing of interaction between law enforcement and customs authorities with the help of information and telecommunication technologies, on the second-unification of customs legislation by amending the Customs Code of Ukraine in terms of excluding the possibility of customs inspection (reinspection) of goods, commercial vehicles on the basis of a law enforcement order with the simultaneous implementation of these actions within the criminal procedure legislation.

Key words: customs law, customs authority, interaction, customs formalities, experimental project.

JEL Classification: K 23, K 38, Z 18.

\section{Natalia BILAK,}

Lawyer,

Candidate of Law natalyodk@gmail.com

orcid.org/0000-0001-8487-8440

\section{Introduction}

Customs security is still one of the main tasks of any state. Herewith, choosing the appropriate vector of national policy in the direction of protection and defense of customs and national interests, states should keep in mind the guarantees of foreign economic activity, which are an important component of national security, an element of the State budget. Therefore, customs policy should be designed in such a way as to minimize any negative impact and risks of pressure on business.

At the same time, Ukrainian state has some gaps in relation of carrying out of rummage (revision) of goods and vehicles of commercial purpose on the initiative of law enforcement agencies, to which attention is paid by scientists and practitioners. A number of changes have been made to the customs legislation even 
experimental project has been implemented, this one is aimed at bringing national legislation and practice of its application to recognized international standards. Despite this, issues of carrying out of rummage (revision) of goods and vehicles of commercial purpose on the initiative of law enforcement agencies, which is not yet resolved, that certifies the relevance of the choice and novelty of its scientific solution.

The purpose of the research is to establishment of theoretical and applied principles of carrying out of rummage (revision) of goods and vehicles of commercial purpose on the initiative of law enforcement agencies by performing research tasks, as following determination of the boundaries of legalization of the procedure for customs inspection (re-inspection) of goods and commercial vehicles on the basis of instructions from law enforcement agencies; separation of the institutionally established system of law enforcement agencies, which are authorized to submit instructions to customs authorities; installation of mechanism of interaction of law enforcement and customs authorities, which is aimed at carrying out of rummage (revision); assessment of the level of efficiency from implementation of experimental project on the organization of submission by law enforcement agencies of instructions for customs inspection (reinspection) with the help of information and telecommunication technologies.

\section{Literature review}

Problems of determining the essential characteristics of accomplishing of rummage (revision) of goods and vehicles of commercial purpose on the initiative of law enforcement agencies needs some attention to be paid at such aspects as scientific interpretation of the main categories of customs law that determine these issues (for example, "rummage", "customs formalities", "customs revision" and others), outlining the grounds and limits of customs inspection, defining the system of law enforcement agencies in accordance with the national concept of legal regulation. Accordingly, to determine the main categories of customs law in this study, the conclusions of following scientists, namely: I.H. Berezhniuk, Y.V. Harmash, Y.V. Donin, N.M. Dukova, S.V. Kivalova, T.O. Kolomoiets, B.A. Kormych, A.V. Mazur, D.V. Pryimachenko, V.V. Prokopenko, V.V. Chentsova and others.

The correct approach is that the customs inspection of territories and premises should be focused on the application after the actual movement of goods and vehicles across the customs border of Ukraine, which determines the specifics of the grounds (special document in the form of a decision of the authorized entity) and purposes of its application (Prokopenko, 2017: 98; Pryimachenko, Prokopenko, 2016: 70). Customs inspection is characterized by a number of features that distinguish it from other types of inspection, in particular: special subject of conducting, which are officials of the customs authority, whose official duties are vested in the authority to conduct customs inspection of goods and commercial vehicles; the object of inspection are goods and vehicles of commercial purpose which are under customs control; exclusive competence of customs authorities to conduct customs inspection; is carried out in the presence of the bases defined by the customs legislation.

The definition of "rummage" is expedient as of the forms of customs control, the implementation of which is attributed to the exclusive competence of customs officials, which is to carry out a set of actions for visual and factual inspection of goods and commercial vehicles under customs control, aimed at verifying the factual data as stated in the documents and/or compliance with customs legislation.

Regarding interpretation of law enforcement agencies, then in the modern sense it's only executive bodies, which in accordance with the legislation, the status and powers of the state law enforcement body are granted to protect important for society and the individual interests, rights and freedoms of man and citizen, ensuring which is a priority of their activities (Rudenko, Shaituro, 2019: 171). At the same time, system of law enforcement agencies can be interpreted as integral, hierarchical, structured set of interconnected and associated law enforcement agencies, by functional criteria aimed at the professional implementation of law enforcement activities to ensure the rule of law and order, protection of rights, freedoms and legitimate interests of individuals, rights and legitimate interests of legal entities, the interests of society and the state from unlawful encroachments (Farion-Melnyk, Yaremko, 2020: 69).

At the same time, large amount of problematic questions of rummage and revision of goods, vehicles of commercial purpose in the initiative of law enforcement remains unresolved in terms of determining the principles of interaction between customs and law enforcement agencies in this area.

\section{Concept of national regulation of carrying out of rummage on the initiative of law enforcement agencies}

General questions regarding the rummage inspection of goods and vehicles of commercial purpose are regulated by Customs Code of Ukraine. Herewith, Customs Code of Ukraine does not contain the definition of "rummage of goods and vehicles of commercial purpose". 
Based on the provisions of the article 336 of Customs Code of Ukraine it can be concluded that in understanding of customs legislation rummage is one of forms of customs control. At the same time, in the specified article the legislator specifying in brackets the corresponding list specifies, that rummage can be divided in three different groups depending on the object of review as following 1) rummage and revision of goods, vehicles of commercial purpose; 2) rummage and revision of hand luggage and luggage; 3) personal inspection of citizens (Customs Code of Ukraine, 2012).

Simultaneously with the term "customs inspection" in the Customs Code of Ukraine is often used such a definition as "inspection", which in many cases is identified by the legislator with the term "customs inspection". In particular, in the article 338 of Customs Code of Ukraine, this is named "Inspection and re-examination of goods, vehicles", which states about existence of several types of inspection of goods, commercial vehicles, which can be used as a result of the application of the risk management system: 1) identification - without opening the packing places and without inspecting the vehicle; 2) partial - with opening of up to 20 percent of packing places and selective inspection of the vehicle; 3 ) full - with the opening of up to 100 percent of the packing places and in-depth inspection of the vehicle; Article 207 of the Customs Code of Ukraine, which states the right of the customs authority to inspect and re-inspect the vessel during its stay under customs control; etc.

Herewith, in other cases, the term "inspection" serves as an independent legal category, which in content should not be equated with the definition of "customs inspection". For example, in paragraph 5 of part 7 of Article 15 of the Customs Code of Ukraine (on the right of customs officials during the conformity assessment to clarify issues related to such assessment to inspect objects (buildings, structures, open or closed areas) etc.) used by the enterprise and relevant for conformity assessment, reflecting the results of such inspection in the relevant act); paragraph 2 of part 1 of Article 203 of the Customs Code of Ukraine (on the possibility of the owner of goods in temporary storage under customs control, or a person authorized by him with the permission of the customs authority to conduct inspection and measurement with these goods) and others.

It should be noted about the existence in national legislation of other terms, at first sight similar or consonant with the terms "customs inspection" and "inspection". In particular, "care" means a security control procedure using technical or other means used to detect weapons, explosives, objects or devices that may be used to commit an act of unlawful interference (On the State Program of Aviation Security of Civil Aviation, 2017); "physical inspection of goods" as a type of inspection that the declarant has the right to conduct before filing a customs declaration subject to obtaining permission from the customs authority to verify the conformity of the description (information) specified in the accompanying documents, sampling and sampling of goods (Customs Code of Ukraine, 2012).

The general basis for the possibility of initiating a review by law enforcement agencies is indirectly provided by Ukraine in Part 5 of article 338 of the Customs Code of Ukraine. Accordingly, the duty of the customs authority to inspect and re-examine goods, commercial vehicles arises, inter alia, in the case of obtaining relevant official information from law enforcement agencies. However, the Customs Code of Ukraine does not clearly indicate the instructions of the law enforcement agency as a basis for customs inspection (re-inspection).

Instead, details of the grounds for inspection (re-inspection) of goods, commercial vehicles are contained in the Resolution of the Cabinet of Ministers of Ukraine (On approval of an exhaustive list of grounds on the presence of which an inspection (re-inspection) of goods, commercial vehicles may be carried out by the bodies of revenues and fees of Ukraine, 2012). It should be noted that this normative legal act, defining such a ground as "receiving relevant official information from law enforcement agencies" details through the wording: "receipt in cases prescribed by law from law enforcement agencies written instructions in the form of criminal proceedings". However, the normative specification of the procedure for initiating a customs inspection at the initiative of a law enforcement agency has not been developed so far. At the same time, this norm contradicts the provisions of the Customs Code of Ukraine in terms of the exclusive competence of customs authorities to determine the boundaries of customs inspection.

Thus, it can be stated that there is no single normative enshrinement of both the concept of customs inspection and the grounds for its application at the initiative of law enforcement, which is a violation of the principle of legal certainty as the basis of any public administration entity. 
The next aspect, which should be resolved, is legal consolidation of law enforcement agencies authorized to initiate customs inspection (re-inspection). It is erroneous for these purposes to pay attention to the provisions of Art. 1 of the Law of Ukraine "On State Protection of Court and Law Enforcement Employees", which bodies endowed with law enforcement or law enforcement functions include: prosecutors, National Police, security service, Military Law Enforcement Service in the Armed Forces of Ukraine, National Anti-Corruption Bureau of Ukraine, security agencies state border, bodies of revenues and fees, bodies and institutions of execution of punishments, pre-trial detention centers, bodies of state financial control, fish protection, state forest protection, etc. (On State Protection of Court and Law Enforcement Officials, 1993).

By the way, normative provisions of profile character, which enshrine the right of law enforcement to initiate inspection (re-inspection) of goods, commercial vehicles, contained in the Resolution of the Cabinet of Ministers of Ukraine "On approval of an exhaustive list of grounds on which inspection (re-inspection) of goods, commercial vehicles by the bodies of revenues and fees of Ukraine". Thus, the entities that may issue instructions include: the investigator, the prosecutor and the investigating judge (On approval of an exhaustive list of grounds on the presence of which an inspection (re-inspection) of goods, commercial vehicles may be carried out by the bodies of revenues and fees of Ukraine, 2012). At the same time, the investigator is an official of the National Police, security body, body supervising compliance with tax legislation, the State Bureau of Investigation, the Main Detective Unit, the Detective Unit, the Detectives Unit, and the Internal Control Unit of the National Anti-Corruption Bureau of Ukraine, competence provided by the criminal procedure legislation to carry out pre-trial investigation of criminal offenses (Criminal Procedure Code of Ukraine, 2012).

Therefore, the system of law enforcement agencies that can initiate inspection (re-inspection) of goods, commercial vehicles are: National Police, security authorities, the body that monitors compliance with tax legislation, the State Bureau of Investigation, the State Bureau of Investigation, the internal control unit of the National Anti-Corruption Bureau of Ukraine, Prosecutor's Office. It is advisable to pay attention to the legalization of the method of submitting a power of attorney from law enforcement to the customs authority to conduct a customs inspection (re-inspection). Thus, the form of the power of attorney is fixed at the regulatory level by determination under the name "power of attorney for inspection (re-inspection) of goods, commercial vehicles". These groups of information must be such that they can be identified and processed and be sufficient for the customs authorities to decide on the inspection (re-inspection) of goods, commercial vehicles (On approval of an exhaustive list of grounds on the presence of which an inspection (re-inspection) of goods, commercial vehicles may be carried out by the bodies of revenues and fees of Ukraine, 2012).

A priority in the digital age is the transfer of correspondence between public authorities in electronic form. It is no exception to submit a power of attorney for customs inspection (re-inspection). It is noteworthy that in Ukraine this practice was tested by the Resolution of the Cabinet of Ministers of Ukraine № 861 of 02.10.2019 (On the implementation of an experimental project on the organization of centralized sending by law enforcement agencies in electronic form of orders for customs inspection (reinspection) of goods, commercial vehicles, 2019). In general, an experimental project on the organization of centralized sending by law enforcement agencies in electronic form of orders for customs inspection (re-inspection) of goods, commercial vehicles. Instead, no further legal regulation was carried out in this direction.

\section{Empirical results}

To solve the problem of lack of jurisdictional procedure for initiating law enforcement agencies to conduct inspections (re-inspections) of goods and commercial vehicles and the availability of an open list of grounds for its application, it is initially necessary to amend Art. 338 of the Customs Code of Ukraine (the proposal is shown in table 1) and the Resolution of the Cabinet of Ministers of Ukraine dated 23.05.2012 № 467 meeting of Ukraine, "On approval of an exhaustive list of grounds on which the inspection (re-inspection) of goods, commercial vehicles by the bodies of revenues and fees of Ukraine", providing for the possibility of inspection of goods and vehicles commercial appointment by law enforcement agencies within the framework of criminal proceedings and in the manner prescribed by criminal procedure legislation (that is, on the basis of a court decision in order to provide temporary access, search and possible seizure of goods). 
Comparison of the current version and the proposed version of paragraph 5 of Art. 338. Customs Code of Ukraine

\begin{tabular}{|c|c|}
\hline Current edition & Proposed edition \\
\hline \multicolumn{2}{|c|}{ Customs Code of Ukraine } \\
\hline $\begin{array}{l}\text { \$ } 5 \text { of Art. 338. Inspection and re-inspection of } \\
\text { goods, vehicles } \\
5 \text {. Except for the cases specified in parts two to four } \\
\text { of this Article, inspection (re-inspection) of goods, } \\
\text { commercial vehicles may be carried out if there are } \\
\text { sufficient grounds to believe that the movement of } \\
\text { these goods, vehicles across the customs border of } \\
\text { Ukraine is carried out outside customs control or } \\
\text { with concealment, from customs control, including } \\
\text { in the case of obtaining relevant official information } \\
\text { from law enforcement agencies. An exhaustive list } \\
\text { of relevant grounds is determined by the Cabinet of } \\
\text { Ministers of Ukraine. For the purpose of inspection } \\
\text { (re-inspection) of goods, customs officials shall } \\
\text { independently take measures provided for by this } \\
\text { Code throughout the customs territory of Ukraine, } \\
\text { including stopping vehicles for inspection (re- } \\
\text { inspection), within the controlled border area and } \\
\text { frontier. Such review (re-review) is carried out at the } \\
\text { expense of the body, on the initiative or on the basis } \\
\text { of the information of which the decision to conduct } \\
\text { it was made. If the inspection (re-inspection) reveals } \\
\text { the fact of illegal movement of goods, commercial } \\
\text { vehicles across the customs border of Ukraine, the } \\
\text { costs associated with the inspection (re-inspection) } \\
\text { are reimbursed by the owner of these goods, vehicles } \\
\text { or his authorized person. }\end{array}$ & $\begin{array}{l}\text { \$ } 5 \text { of Art. 338. Inspection and re-inspection of } \\
\text { goods, vehicles } \\
5 \text {. Except for the cases specified in parts two to four } \\
\text { of this Article, inspection (re-inspection) of goods, } \\
\text { commercial vehicles may be carried out if there } \\
\text { are sufficient grounds to believe that the movement } \\
\text { of these goods, vehicles across the customs border } \\
\text { of Ukraine is carried out outside customs control } \\
\text { or with concealment, from customs control, } \\
\text { including in the case of obtaining relevant official } \\
\text { information from law enforcement agencies. Such } \\
\text { review (review) is carried out in accordance with } \\
\text { the criminal procedure legislation. An exhaustive } \\
\text { list of other grounds is determined by the Cabinet of } \\
\text { Ministers of Ukraine. For the purpose of inspection } \\
\text { (re-inspection) of goods, customs officials shall } \\
\text { independently take the measures provided for in this } \\
\text { Code throughout the customs territory of Ukraine, } \\
\text { including stopping vehicles for inspection (re- } \\
\text { inspection), within the controlled border area and } \\
\text { border strip. Such review (re-review) is carried out } \\
\text { at the expense of the body, on the initiative or on } \\
\text { the basis of the information of which the decision to } \\
\text { conduct it was made. If the inspection (re-inspection) } \\
\text { reveals the fact of illegal movement of goods, } \\
\text { commercial vehicles across the customs border of } \\
\text { Ukraine, the costs associated with the inspection } \\
\text { (re-inspection) are reimbursed by the owner of these } \\
\text { goods, vehicles or his authorized person. }\end{array}$ \\
\hline
\end{tabular}

Making these changes is the ultimate way to reform the customs inspection (re-inspection) at the initiative of law enforcement. The first step should be to intensify the use of information and telecommunications technologies in the interaction of law enforcement and customs authorities.

Assessing the level of efficiency from the implementation of the pilot project to organize the submission of orders by law enforcement agencies for customs inspection (re-inspection) using information and telecommunications technology, we note that during the pilot project law enforcement agencies - its participants sent to customs authorities more than 200 orders (the instructions were sent by the SBU, the Office of the Prosecutor General of Ukraine, the National Police of Ukraine, the State Border Guard Service of Ukraine, the SFS (tax police)).

In order to ensure proper processing of orders of law enforcement bodies of the SCSU, the Order of processing of orders and inspection (re-inspection) of goods, commercial vehicles was developed and approved by the order of 11.02.2020 № 50. At the same time according to the information received by the SCSU among law enforcement agencies, only the National Police of Ukraine issued an order dated 25.02.2020. There is no information on determining the procedure for centralized sending in electronic form of orders for inspection (re-inspection) of goods, commercial vehicles by other law enforcement agencies by issuing the relevant administrative documents in the SCSU (On the results of the experimental project, 2020).

Thus, there is a low level of regulatory specification of the provisions on electronic submission of orders for customs inspection (re-inspection). At the same time, due to the possibility of sending orders in paper form, the practice of electronic means did not spread. The reason for this may be that the electronic 
method marks the need to comply with the principle of legality and consistency. While paper, allows you to correlate the procedure for submitting orders for customs inspection (re-inspection). A possible way to address these gaps is to introduce a single electronic form of sending orders from law enforcement to customs.

\section{Conclusions}

As a result of the research: the author's definition of the concept of "customs inspection" is offered; the system of law enforcement bodies which can initiate inspection (re-inspection) of the goods, vehicles of commercial appointment according to the current legislation is defined; the state of introduction of information and telecommunication technologies in the sphere of interaction of customs and law enforcement bodies is established. A two-stage approach to reforming the customs inspection (re-inspection) of goods and commercial vehicles on the basis of a written order from law enforcement agencies is proposed. At the first stage it is proposed to tax the interaction between law enforcement and customs authorities with the help of information and telecommunication technologies, and at the second to unify customs legislation by amending the Customs Code of Ukraine to exclude the possibility of customs inspection (re-inspection) of goods and commercial vehicles, instructions of the law enforcement body with the simultaneous implementation of these actions within the criminal procedural legislation.

\section{References:}

1. Prokopenko, V.V. (2017). Ohliad terytorii ta prymishchen skladiv tymchasovoho zberihannia, mytnykh skladiv, vilnykh mytnykh zon, mahazyniv bezmytnoi torhivli yak forma mytnoho kontroliu [Inspection of territories and premises of temporary storage warehouses, customs warehouses, free customs zones, duty-free shops as a form of customs control]. Visnyk Chernivetskoho fakultetu Natsionalnoho universytetu "Odeska yurydychna akademiia", no. 1, pp. 85-99 [in Ukrainian].

2. Pryimachenko, D.V., Prokopenko, V.V. (2016). Perevirka obliku tovariv, transportnykh zasobiv komertsiinoho pryznachennia, shcho peremishchuiutsia cherez mytnyi kordon Ukrainy ta/abo perebuvaiut pid mytnym kontrolem yak forma mytnoho kontroliu [Verification of accounting of commodities, commercial vehicles moving across the customs border of Ukraine and/or under customs control as a form of customs control]. Lex Portus, no. 1, pp. 64-77 [in Ukrainian].

3. Rudenko, M., Shaituro, O. (2019). Poniattia ta systema pravookhoronnykh orhaniv (orhaniv pravoporiadku) u konteksti novoho zakonu "Pro natsionalnu bezpeku Ukrainy": pytannia pravovoi vyznachenosti [The concept and system of law enforcement agencies (law enforcement agencies) in the context of the new law "On National Security of Ukraine": the issue of legal certainty]. Visnyk Luhanskoho derzhavnoho universytetu vnutrishnikh sprav imeni E.O. Didorenka, no. 1(85), pp. 165-172. DOI: https://doi.org/10.33766/2524-0323.85.165-172 [in Ukrainian].

4. Farion-Melnyk, A., Yaremko, O. (2020) Pravookhoronni orhany: pytannia terminolohii ta systemy [Law enforcement: terminology and system issues]. Aktualni pytannia pravoznavstva, no. 2, pp. 65-70 [in Ukrainian].

5. Mytnyi kodeks Ukrainy: Zakon Ukrainy vid 13.03.2012 r. № 4495-VI [Customs Code of Ukraine]. Retrieved from: https://zakon.rada.gov.ua/laws/show/4495-17\#Text [in Ukrainian].

6. Pro Derzhavnu prohramu aviatsiinoi bezpeky tsyvilnoi aviatsii: Zakon Ukrainy vid 21.03.2017 r. № 1965-VIII [About the State program of aviation safety of civil aviation]. Retrieved from: https://zakon.rada.gov.ua/laws/show/1965-19/ed20170321\#n93 [in Ukrainian].

7. Pro zatverdzhennia vycherpnoho pereliku pidstav, za naiavnosti yakykh mozhe provodytys ohliad (pereohliad) tovariv, transportnykh zasobiv komertsiinoho pryznachennia orhanamy dokhodiv i zboriv Ukrainy: Postanova Kabinetu Ministriv Ukrainy vid 23.05.2012 r. № 467 [About the statement of the exhaustive list of the bases in the presence of which inspection (re-inspection) of commodities, vehicles of commercial appointment by bodies of income and fees of Ukraine can be carried out]. Retrieved from: https://zakon.rada.gov.ua/laws/show/467-2012-\%D0\%BF\#n10 [in Ukrainian].

8. Pro derzhavnyi zakhyst pratsivnykiv sudu i pravookhoronnykh orhaniv: Zakon Ukrainy vid 23.12.1993 r. № 3781-XII [About state protection of employees of court and law enforcement agencies]. Retrieved from: http://zakon3.rada.gov.ua/laws/show/3781-12 [in Ukrainian].

9. Kryminalnyi protsesualnyi kodeks Ukrainy: Zakon Ukrainy vid 3.04.2012 № 4651-VI [Criminal Procedure Code of Ukraine]. Retrieved from: https://zakon.rada.gov.ua/laws/show/ 465117 ? find $=1$ \& te $\mathrm{t}=\% \mathrm{D} 0 \% \mathrm{~B} 4 \% \mathrm{D} 0 \% \mathrm{BE} \% \mathrm{D} 1 \% 80 \% \mathrm{D} 1 \% 83 \% \mathrm{D} 1 \% 87 \% \mathrm{D} 0 \% \mathrm{~B} 5 \% \mathrm{D} 0 \% \mathrm{BD} \% \mathrm{D} 0 \%$ BD\%D1\%8F\#w1_1 [in Ukrainian].

10. Pro realizatsiiu eksperymentalnoho proektu $\mathrm{z}$ orhanizatsii tsentralizovanoho nadsylannia pravookhoronnymy orhanamy $\mathrm{v}$ elektronnomu vyhliadi doruchen na provedennia mytnoho ohliadu 
(pereohliadu) tovariv, transportnykh zasobiv komertsiinoho pryznachennia: Postanova Kabinetu Ministriv Ukrainy vid 02.10.2019 r. № 861 [About realization of the experimental project on the organization of the centralized sending by law enforcement agencies in electronic form of instructions for carrying out customs inspection (re-inspection) of commodities, vehicles of commercial function]. Retrieved from: https://zakon.rada.gov.ua/laws/show/861-2019-\%D0\%BF\#Text [in Ukrainian].

11. Pro rezultaty realizatsii eksperymentalnoho proektu: Lyst Derzhavnoi mytnoi sluzhby vid 08.07.2020 r. № 08-1/20-01/3/7588 [About results of realization of the experimental project]. Retrieved from: ileview.fwdcdn.com/?url=https\%3 A\%2F\%2Fmail.ukr.net $\% 2$ Fapi\%2Fpublic $\% 2$ Ffile view\%2Flist\%3Ftoken\%3Dh0_knNZUtIU6hL5iNXcND2sMcbPYwrhy8qcMsyQrYK9CJinnEGRt8YvGJfdm2AZ_ S2xDGLsuPrxBrntejPTOSd7MF85C [in Ukrainian].

\title{
ЩОДО ПИТАННЯ ПРОВЕДЕННЯ МИТНОГО ОГЛЯДУ НА ПІДСТАВІ ДОРУЧЕННЯ ПРАВООХОРОННОГО ОРГАНУ
}

\author{
Наталія БІЛАК, \\ адвокат, \\ кандидат юридичних наук \\ natalyodk@gmail.com \\ orcid.org/0000-0001-8487-8440
}

\begin{abstract}
Метою дослідження є встановлення сутнісних характеристик здійснення митного огляду (переогляду) товарів та транспортних засобів комериійного призначення за ініціативою правоохоронних органів.

Методологічну основу наукового дослідження, логіку уявлення дослідженого матеріалу становили загальні та спеціальні методи наукового пізнання (метод системного аналізу, діалектичний метод, формальнологічний та структурно-функціональний методи), а також низка емпіричних методів.

Результати. У статті розкрито теоретико-прикладні аспекти проведення митного огляду (переогляду) товарів, транспортних засобів комериійного призначення на підставі письмового доручення правоохоронних органів. Проаналізовано порядок взаємодії митних та правоохоронних органів у питанні здійснення митних формальностей. Встановлено суперечність між нормами чинного митного законодавства стосовно посягання на виключну компетенцію митних органів щодо здійснення митного контролю та обрання обсягу митних формальностей із боку правоохоронних органів. Звернено увагу на стан реалізаџї експериментального проєкту з організації централізованого надсилання правоохоронними органами в електронному вигляді доручень на проведення митного огляду (переогляду) товарів, транспортних засобів комериійного призначення. Запропоновано напрями подальшого використання інформаційнотелекомунікаційних технологій у взаємодї митних та правоохоронних органів.

Висновки. Визначено поняттяя «митний огляд» як одну з форм митного контролю, здійснення якої віднесене до виключної компетениії посадових осіб митного органу, що полягає у здійсненні сукупності дій щодо візуального й фактичного огляду товарів і транспортних засобів комериійного призначення, які перебувають під митним контролем, спрямованих на перевірку фактичних даних на відповідність тим, що заявлені в документах, та стосовно дотримання митного законодавства. При ивому вибір підстав і меж митного огляду здійснюється виключно в межсах, які визначені Митним кодексом України. Штучне розширення окремих елементів механізму проведення митного огляду (переогляду) товарів, транспортних засобів комериійного призначення на підставі підзаконних нормативно-правових актів є порушенням принципу верховенства права. Запропоновано двоетапний підхід реформування прочедури проведення митного огляду (переогляду) товарів, транспортних засобів комериійного призначення на підставі письмового доручення правоохоронних органів. На першому етапі пропонується налагодження взаємодії правоохоронних і митних органів за допомогою інформаційно-телекомунікаиійних технологій, а на другому - уніфікаиія митного законодавства шляхом внесення змін до Митного кодексу України в частині виключення можливості проведення митного огляду (переогляду) товарів, транспортних засобів комериійного призначення на підставі доручення правоохоронного органу з одночасним здійсненням иих дій у межах кримінального проиесуального законодавства.
\end{abstract}

Ключові слова: митне право, митний орган, взаємодія, митні формальності, експериментальний проєкт. 